\title{
日本における白金族金属のリサイクルポテンシャル評価
}

\section{栗木辰悟* 醍醐市朗松野泰也足立芳寛}

\author{
東京大学工学系研究科マテリアル工学専攻
}

J. Japan Inst. Metals, Vol. 74, No. 12 (2010), pp. 801-805

(C) 2010 The Japan Institute of Metals

\section{Recycling Potential of Platinum Group Metals in Japan}

\author{
Shingo Kuriki*, Ichiro Daigo, Yasunari Matsuno and Yoshihiro Adachi \\ Department of Materials Engineering, Graduate School of Engineering, The University of Tokyo, Tokyo 113-8656
}

\begin{abstract}
The production of the platinum group metals (PGM) consumes large quantities of energy and induces a lot of carbon dioxide. The promotion of PGM recycling is important to construct a sound material-cycle society. In this article, a dynamic material flow analysis for PGM in Japan was conducted in order to evaluate the recycling potential of PGM. In Japan, PGM demand for autocatalyst accounted for about 50\% of the total PGM demand in 2008. Therefore, this study focused on platinum, palladium, and rhodium used as autocatalyst. The amount of material stock regarding these autocatalysts were estimated during 1975-2008. The amount of these autocatalysts generated from end-of-life vehicles (ELV) were also estimated during 1988-2008.

As the result, the material stock of these metals as autocatalysts has monotonically increased during the investigated period. The amount of these autocatalysts generated from ELV has also increased, but the amount of recycled ones have been rather stable due to growing exportation of used automobiles, used auto engines, and used autocatalysts.
\end{abstract}

(Received June 25, 2010; Accepted August 23, 2010)

Keywords: dynamic material flow analysis, platinum group metals, autocatalyst

\section{1. 緒言}

白金族金属とは, Pt, Pd, Rh, Ru, Ir, Os の総称であり, PGM (the platinum group metals)とよばれている. PGM は, 高融点, 高強度, 高触媒性能などの特性があり, 工業的 に重要な元素である。しかしながら, 天然資源としての PGM は極端に偏在しているため, 常に供給リスクを伴って いる。 また, 鉱石中の $\mathrm{PGM}$ の含有率は $3 \sim 7 \mathrm{ppm}$ 程度 ${ }^{1)}$ あり，Ptを 1 トン製造するのに 4 万トンの $\mathrm{CO}_{2}$ が誘発さ れ，またTMR (Total Material Requirement)は 68 万トンと 環境負荷が大きい2). そのため, 使用済み製品からの PGM リサイクルの促進が望まれている. 近年, 素材や物質の, 社 会中での物質フローと物質ストック量を推計する, マテリア ルフロー分析 (Material Flow Analysis, MFA)が盛んに行わ れてきている. PGM に関しては, 中條と中村 ${ }^{3}$, 岡部と中

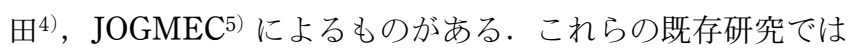
静的な分析を行って抢り, 単年のフローを示している.リサ イクルのフローは，過去の製品の投入量などの影響を受ける ため, 単年のフローではリサイクルのフローを推計するのが 困難である.

リサイクルのフローを把握するための手法として, 動的 MFA がある ${ }^{6)}$. 動的 MFA は, 過去の製品の社会中への投 入量や寿命分布から, 将来の物質ストック量やスクラップ発

\footnotetext{
* 東京大学大学院生 (Graduate Student, The University of Tokyo)
}

生量を推計する手法である. 動的 MFA には，トップダウン 手法とボトムアップ手法の二つの手法がある. 前者は, 各種 素材の生産統計や産業連関表などの統計データと, 素材の最 終用途製品の寿命分布から, 社会中の物質ストック量を推計 するものである. それに対して後者は, 統計データなどが得 られない場合に，対象とする地域において使用されている製 品の数を推計し，その製品中の原単位から素材の物質ストッ ク量を推計するものである7).

原田ら ${ }^{8)}$ は, 日本における PGM の使用量を 1995 年から 2005 年まで解析し, 各製品の物質ストック量を推計してい る. そこでは各製品は一定の使用期間後に廃棄されるとし て, 寿命分布を考慮せずにスクラップ発生量を推計してい る. しかし, この方法では, 製品の投入量が大きく増減する と, スクラップ発生量も大きく増減する結果となる. 実際の 製品は, 投入されてから法的耐用年数後にすべて廃棄される わけではない，製品の寿命には分布があり，スクラップ発生 量は過去の製品の投入量と寿命分布の履歴に依存する.さら に，PGM の主用途である自動車は平均寿命が 10 年をこえ るため, 正確な物質ストック量および排出量を推計するため には, 20 年以上を考慮した分析が必要である.

また, SauratとBringezu2,9) は, 欧州における PGM の動 的 MFA を実施し, 自動車触媒に使用される PGM の物質ス トック量を, 2020 年まで推計している. そこでは, ボトム アップ手法を用いて推計して抢り，自動車一台当たりの PGM 使用原単位は, 燃料, シリンダー容量, 排ガス規制值 により異なると言及している。しかしながら, 日本を対象と 


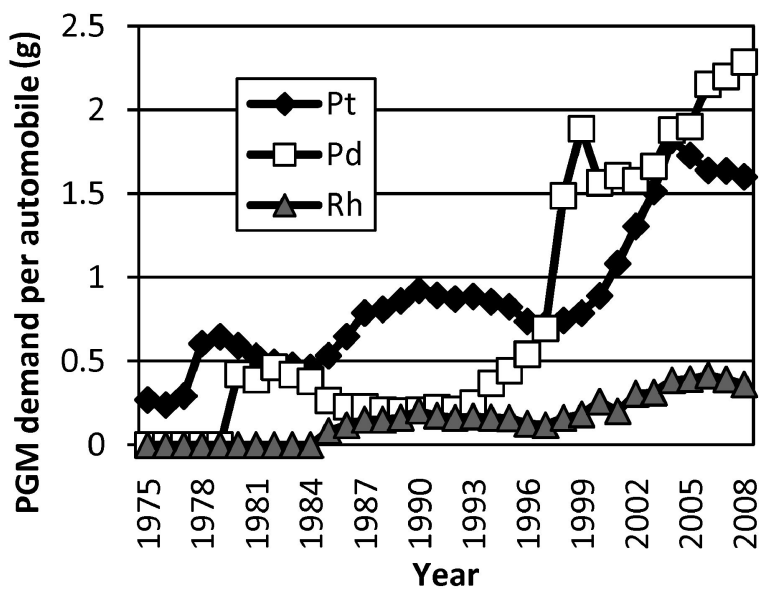

Fig. 1 PGM demand per automobile in Japan.

して，使用原単位の経年変化を考慮した精緻なデータを用い た研究は行われていないのが現状である.

日本で生産される自動車 1 台あたりの PGM 需要量は, Fig. 1 に記すように推移して抢り10,11)，自動車 1 台あたりの PGM 使用原単位は, 経年で大きく変化していることが分か る。これは, 素材価格が大きく増减していることや, 企業が PGM 使用量を小さくするために技術水準の向上に努めてい ることなど, 複数の要因がある. また，製造年だけでなく， 車種によっても自動車 1 台あたりの PGM 使用原単位は異な る. しかし, 原単位は自動車メーカーが対外的に公表するも のではなく，詳細なデータを入手することはできない，その ため, 自動車の台数に使用原単位を乗じる方法で, PGM の フローおよび物質ストック量を推計することは，困難である と考えられる.

さらに, 日本の場合, 使用済反自動車 (end-of-life vehicles, ELV) 抢よび自動車部品の海外への輸出が多く ${ }^{12)}$ ，それ に伴い多くの PGM が流出している点も指摘されている13). したがって，PGM の動的 MFA を実施するためには，ELV 抢よび自動車部品の海外輸出による流出量の把握が必須であ る.しかし, ELV 抢よび自動車部品の海外輸出量の経年変 化を，定量的に分析した研究は行われていない.

そこで本研究では, 製品の寿命分布を考慮したトップダウ ン手法により動的 MFA を行い，日本における PGM のリサ イクルのフローを明確にし，そのリサイクルポテンシャルを 明らかにすることを目的とする。対象期間は，1975 年から 2008 年までとする.

\section{2. 研 究手 法}

\section{1 評価対象}

PGM の主要な工業用途は, 自動車の排ガス浄化触媒, 化 学プロセス用触媒, ガラス工業用るつほ, 歯科材料, 電子部 品である. 化学プロセス用触媒や，ガラスの溶解に使用され るるつぼは, 劣化するとリサイクル業者に委託処理され, 再 び同じ設備で利用されており, 既に PGM のサイクルが確立 している2,14-16)。歯科材料とは, 主に歯冠修復材のことであ る. 電子部品は, 多層セラミックコンデンサなどに使用され
ているが，電子部品用 PGM 需要量は日本における PGM 需 要量の $20 \%$ に満たない10). その他, PGM の大きな用途の一 つに宝飾品があるが，そのほとんどを個人消費者が退蔵して いると考えられる14)。そこで, 本研究では, 日本における PGM 需要量の約 50\%を占好自動車触媒に着目し, 自動車 触媒に使用されている $\mathrm{Pt}, \mathrm{Pd}, \mathrm{Rh}$ を対象とした。

\section{2 動的分析手法}

動的分析には, 自動車触媒用 PGM の国内投入量, 自動車 の寿命分布が必要である．これらを推計するのに用いたデー タおよび計算方法を以下に示す.

日本の自動車触媒用 PGM 需要量は, Johnson Matthey 社 の統計 ${ }^{10)}$ に, Pt については 1975 年から 2008 年, Pd につ いては 1980 年から 2008 年までのデータが記されている. また，Rhについては，世界の自動車触媒用需要量のデータ はあるが，日本の自動車触媒用需要量のデータがない，その ため, 日本の自動車触媒用 $\mathrm{Rh}$ 需要量は, 世界の自動車触媒 用 $\mathrm{Rh}$ 需要量が世界の自動車触媒用 $\mathrm{Pt}, \mathrm{Pd}$ 需要量の和に対 する割合に, 日本の自動車触媒用 $\mathrm{Pt}, \mathrm{Pd}$ 需要量の和を乗じ たものとした。しかし，この需要量とは，日本で生産される 自動車全体の需要量であり, 日本で生産される自動車の半数 が輸出されていることを考慮する必要がある. そこで, 日本 に抢ける自動車触媒用 PGM の国内投入量は, 日本の自動車 触媒用 PGM 需要量に, 日本の自動車生産台数に占好 日本 の自動車新規登録台数の割合を乗じたものとした．自動車の 生産台数, 自動車の新規登録台数は, それぞれ世界自動車統 計年報11)

また，統計17)より，各年 3 月末に打ける初度登録年別自 動車保有台数が 1975 年から 2008 年まで得られる。これは 年度別のデータであるため, 登録年翌年 3 月末の保有台数 を，登録年末の保有台数とした。初度登録年を製造年々考 え，製造年に製造された自動車は製造年末時点で 1 台も ELV とならず，すべて使用されているとした．各年末の自 動車保有台数を，製造年末時点での自動車保有台数で割る と，自動車の寿命分布となる.

\section{3 使用済み自動車のフローの把握}

日本で発生する ELV は, 中古自動車として輸出された り, そのうちの一部の部品が中古部品として輸出されたりす るため，すべて国内でスクラップになるとは限らない，中村 ら ${ }^{13)}$ が, 詳細な調查により 2005 年における日本で発生する ELV のフローを明らかにしている。このフローのうち， $\mathrm{ELV}$ の発生台数, 中古自動車の輸出台数, 中古エンジン輸 出量を変数として, ELV のフローを 1988 年から 2008 年ま で推計した. ELVの発生台数は, 推計年前年の自動車保有 台数々推計年の自動車新規登録台数の和から推計年の自動車 保有台数を引いたものとした. 中古自動車の輸出台数は, 1988 年から 2005 年は布施と鹿島 12 )が推計した值を使用し た．ただし，この論文で解析されていない 2006 年以後は統 計18)の值を使用した。中古エンジン輸出量は, 1988 年から 2005 年は布施と鹿島が推計した值を使用した。2006 年から 2008 年は, 布施と鹿島が推計した，2005 年に抢ける中古自 
動車輸出台数に対する中古エンジン輸出量の割合に, 統 計 ${ }^{18)} の$ 中古自動車輸出台数を乗じて求めた.

3. 研 究 結 果

\section{1 リサイクルポテンシャル}

日本国内の自動車触媒に使用される PGM の物質ストック 量 (Fig. 2), 日本国内の ELVの発生に伴うPGM の排出量 (Fig. 3)を導出した.

1990 年代前半までは自動車触媒には主に Pt が用いられて きたが，技術水準の向上により，それまで Ptで担ってきた 機能が Pt に比べて価格の安い Pd で代替できるようになっ たため ${ }^{14)}, 1998$ 年頃に $\mathrm{Pd}$ の需要量が大きく増加した．こ れに伴い，Pdの物質ストック量も 1998 年頃から大きく増 加している(Fig. 2)．Pd の物質ストック量の増加により，5 年後の 2003 年頃から ELVの発生に伴う Pdの排出量が大き く増加していることが確認できる(Fig. 3)。しかし Pd 価格 は大きく増減しており，Pd 価格が大きく上昇した 2001 年 頃から再び Pt が多く使用されるようになった。これは $\mathrm{Pt}$ の物質ストック量, ELVの発生に伴う Pt の排出量の増加に

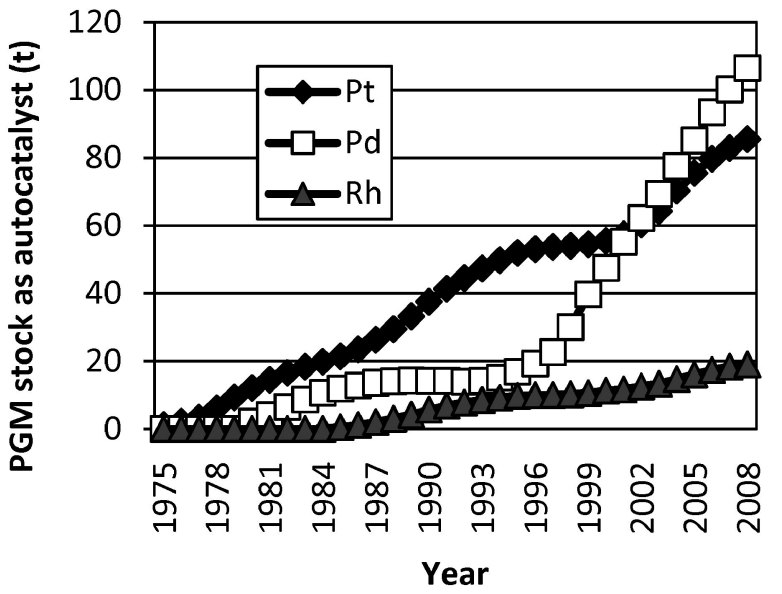

Fig. 2 Estimated amount of material stock of PGM as autocatalyst in Japan.

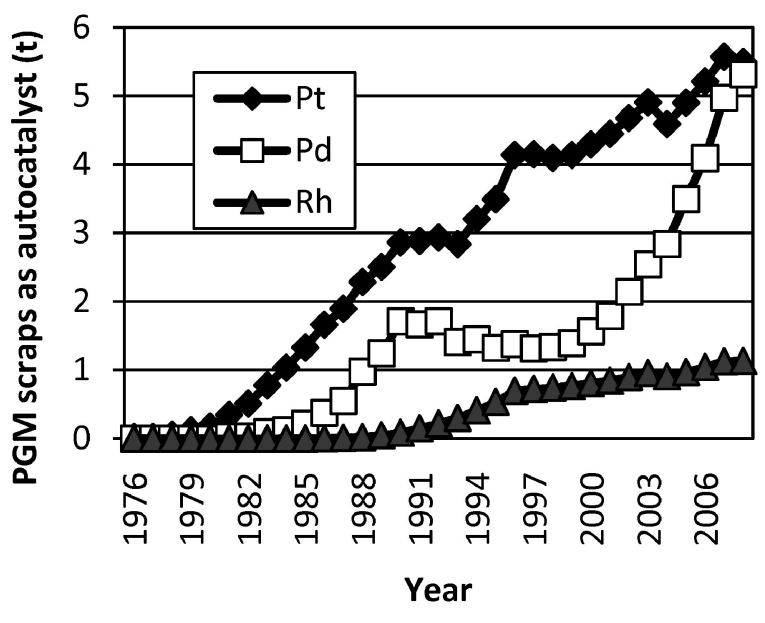

Fig. 3 Estimated amount of PGM scraps as autocatalyst generated from end-of-life vehicles in Japan.
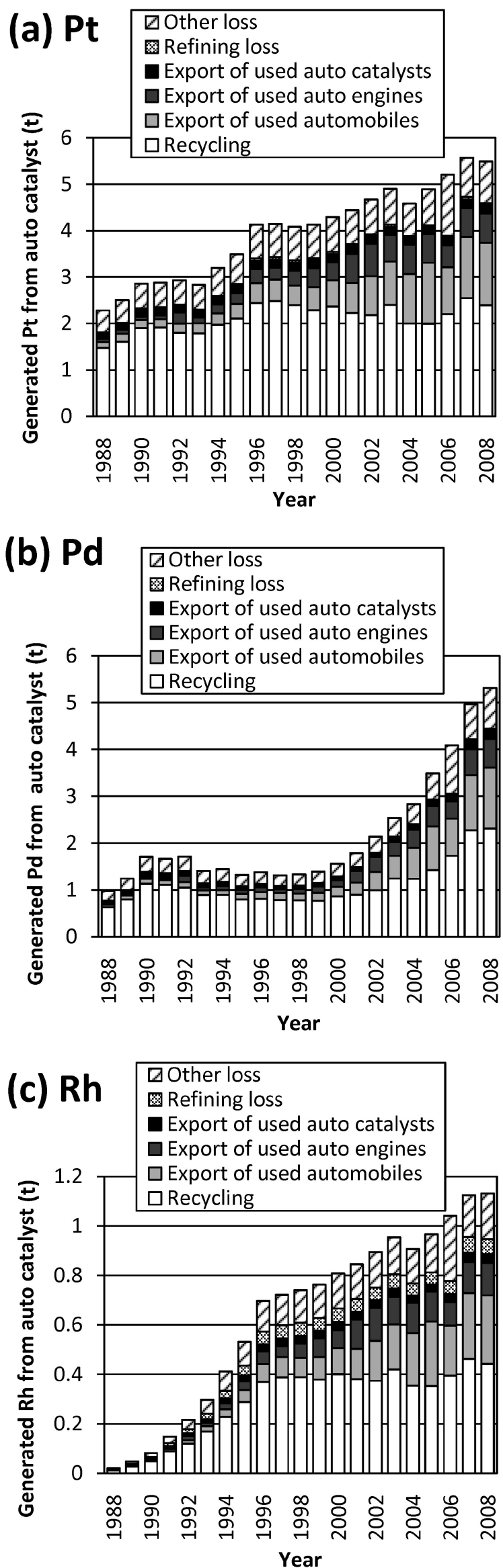

Fig. 4 Destination of PGM generated from autocatalyst in end-of-life vehicles in Japan. (a) Pt, (b) Pd and (c) Rh. 


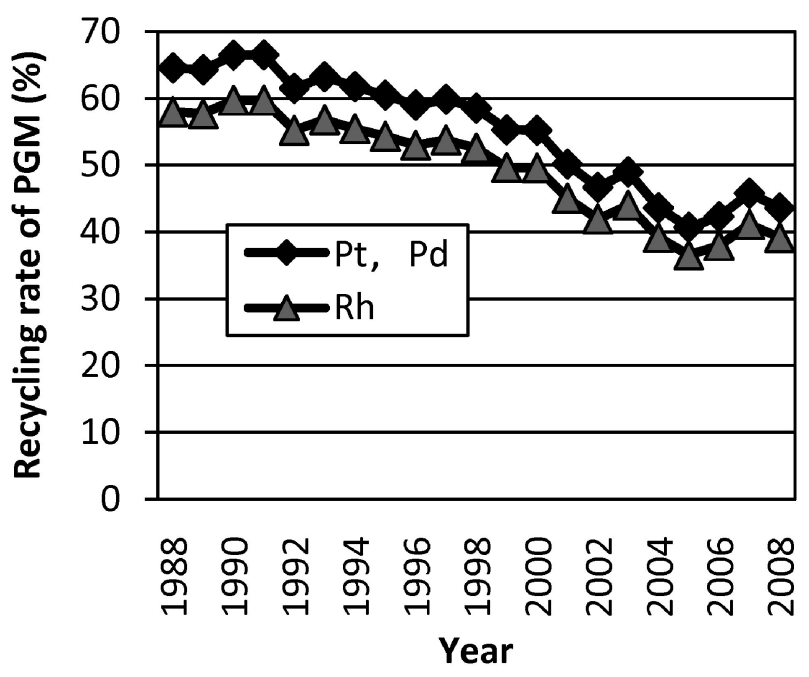

Fig. 5 Recycling rate of PGM as autocatalyst in Japan. (The recycling rate of PGM denotes the ratio of the amount of recycled PGM to the amount of PGM generation as autocatalyst in Japan.)

反映されている(Fig. 2, Fig. 3)。日本における自動車触媒用 PGM の物質ストック量は, 2008 年では Pt が 85.5 トン, Pd が 106.5 トン, Rh が約 17 トンとなった. 原田ら孚が推 計した， 2005 年における自動車触媒用 PGM の物質ストッ ク量は Pt, Pd, Rh の合計が 115.0 トンである。それに対し て本研究では 176.6 トンとなり，大きな差が見られた。これ は，原田らは過去 7 年分の投入量の和を物質ストック量と しているのに対し，本研究では，1975 年からの投入量と自 動車の寿命分布を考慮しているためであると考えられる．本 研究により, より正確な物質ストック量が推計できたと考え られる。

日本国内の ELV の発生に伴う PGM の排出量は, 2008 年 では Pt が 5.5 トン, Pd が 5.3 トン, Rh が約 1 トンとなっ た. 2008 年の日本に抢ける自動車触媒用 PGM 需要量は Pt が 18.5 トン, $\mathrm{Pd}$ が 26.4 トン, Rh 約 9 トンであり, 排出量 と大きな差が見られる。これは， 2008 年に打ける排出量は 過去の投入量に依存し, 投入された PGM の約半数は輸出車 として海外に流出しているためである.

\section{2 使用済み自動車のフロー}

2.2 で推計した, 日本国内の ELVの発生に伴う PGM の 排出量と, ELV のフローから, 自動車触媒に用いられる PGM の回収量, 輸出による流出量, 精錬ロス, その他ロス の経年変化を推計した $($ Fig. $4(\mathrm{a}) \sim(\mathrm{c}))$. 回収量とは, 日本 で発生し, 回収された ELV から, 国内の精錬業者により精 錬されたPGM の量を示す. 輸出による流出量とは, 中古自 動車, 中古エンジン, 中古触媒の輸出による PGM の流出量 を示す，精鍊ロスとは，精錬時の歩留をりを示す．その他口 スとは, 解体業者による ELV からの触媒回收時のシュレッ ダーロス, ELV や触媒の滞留, 行き先不明等によるロスを 示す。また，日本国内の ELV の発生に伴う PGM の排出量 に対する，自動車触媒からの PGM の回収量の割合をリサイ クル率として計算した(Fig. 5). (a) Pt

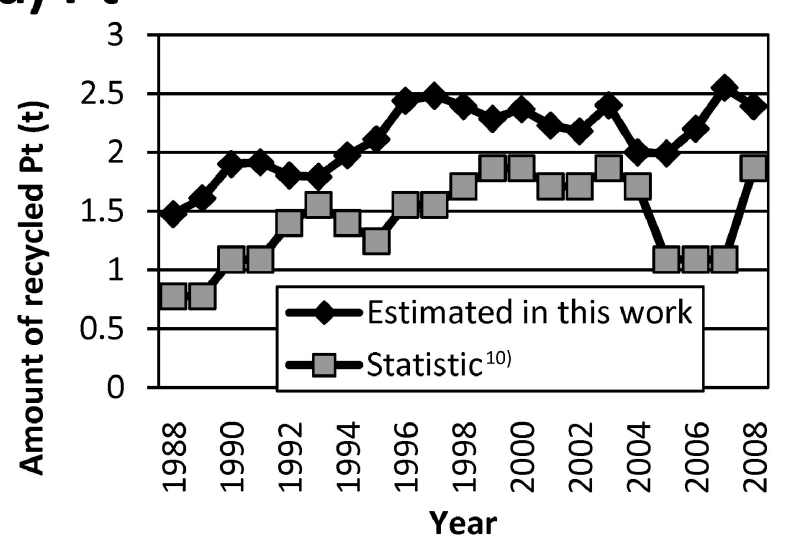

(b) Pd

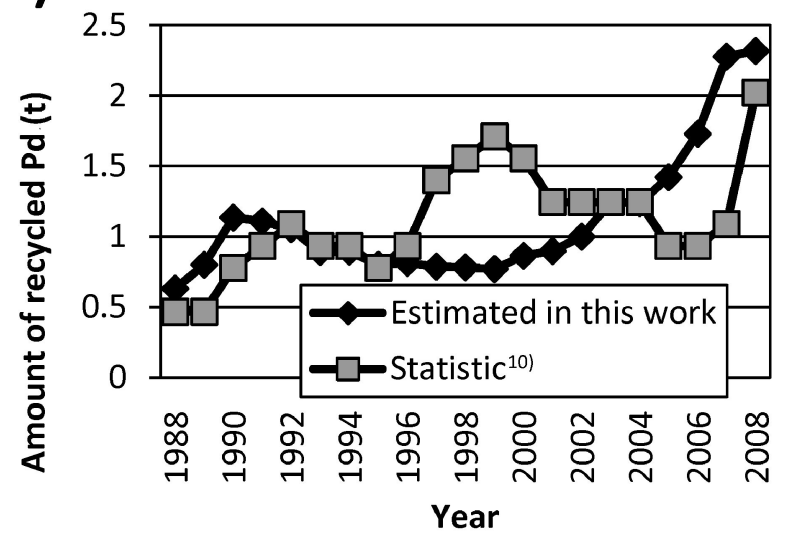

(c) $\mathrm{Rh}$

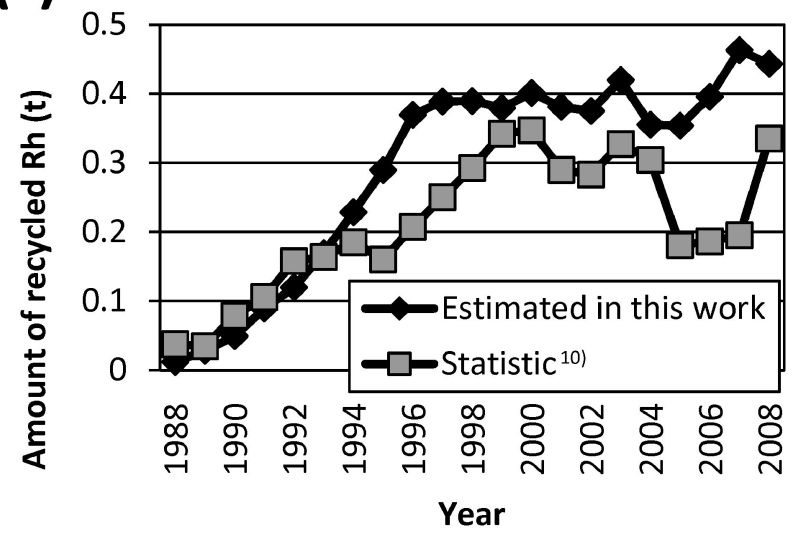

Fig. 6 The comparison between the estimation and the statistic of recycled PGM as autocatalyst in Japan. (a) Pt, (b) Pd and (c) $\mathrm{Rh}$.

ELV の発生に伴うPGM の排出量は年々増加している が，回収量はあまり変化していない，これは，中古車，中古 エンジン, 中古触媒の輸出による PGM の海外への流出量が 大きくなったためである. ELV 発生に伴う PGM の排出量 に対する, 中古車, 中古エンジン, 中古触媒の輸出による

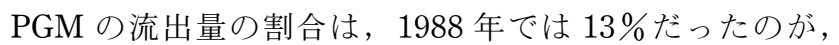
2008 では $43 \%$ まで増加している. 1988 年のリサイクル率 は Pt, Pdが $65 \%, \mathrm{Rh}$ は $58 \%$ だったのが，2008 年では Pt, Pd が 44\%, Rh が 39\%まで減少していることが分かった。 


\section{4. 考察}

本研究により，国内で発生する ELVから回収された PGMの量が推計された一方, Johnson Matthey 社の統計10) に，自動車触媒からの PGM の回収量が記されている。しか し, 日本において PGM の回収量は一次統計の対象外であ り 15), Johnson Matthey 社が公表している統計值が一次統計 ほどの確度があるとは限らない。そこで, 推計值と統計值を 比較することで, 本研究で得た推計結果および統計值の妥当 性を考察した(Fig. 6(a)〜 (c)).

Pt の回収量は, 全体的に統計值よりも推計值の方が大き い.これは, 次のような理由が考えられる. 現在, ディーゼ ル車に使用される PGM のうち Pt が占める割合は，ガソリ ン車に使用される $\mathrm{PGM}$ のうち $\mathrm{Pt}$ が占める割合よりも大き い. そして，日本からの自動車輸出台数が北米に次いで多い 欧州では, ディーゼル車が新車販売台数の約半数を占める. よって, 国内で生産された自動車が輸出される時点で, $\mathrm{Pt}$ が Pd Ph よりも多く流出して抢り，実際に Pt が国内に 投入された量は，推計した Pt の国内投入量よりも小さかっ たと考えられる。

$\mathrm{ELV}$ から回収された $\mathrm{Pt}, \mathrm{Pd}, \mathrm{Rh} の$ 量は, ともに推計值と 統計值が概ね近い值となっており，本研究の手法による推計 結果と統計の值が妥当であることが確認された。よって, Fig. 3 のように, 今後, PGM のスクラップ量が増加すると 言える。また，Fig. 4(a)〜 (c)のように，ELV からの PGM の回収量は輸出による影響が大きい。特に, 中古エンジンの 輸出によるPGM の流出量は, ELV の発生に伴うPGM の 排出量の約 $10 \%$ と大きいにもかかわらず，中古エンジンの 輸出量はほとんど把握されていない。資源戦略上の観点から もこれらの輸出量の把握が必要であり, 統計等の整備が望ま れる。

\section{5. 結 言}

動的 MFA により，日本に抢いて自動車用触媒として使用 される $\mathrm{Pt}, \mathrm{Pd}, \mathrm{Rh} の, \mathrm{ELV}$ からの発生後のフローを明らか にし，日本における PGM のリサイクルポテンシャルを定量
的に分析した。自動車触媒用 PGM の物質ストック量は, 2008 年では Pt が 85.5 トン, Pd が 106.5 トン, Rh が約 17 トンと推計された. ELVの発生に伴う $\mathrm{Pt}, \mathrm{Pd}, \mathrm{Rh}$ の排出量 は年々増加しているのにもかかわらず, 中古自動車, 中古工 ンジン, 中古触媒の輸出量増加による資源流出のため, 国内 での回収量はあまり変化していないことが分かった。

文

\section{献}

1) T. Okabe and H. Nakada: Catalysts \& Catalysis $\mathbf{5 0}$ (2008) 350357.

2) M. Saurat and S. Bringezu: Journal of Industrial Ecology 12 (2008) 754-767.

3) H. Nakajo and T. Nakamura: Technology of Alternatives and Recycling of Rare Metals, (CMC Publishing Co., Ltd., Tokyo, 2008) pp. 248-271.

4) T. Okabe and H. Nakada: Technology of Alternatives and Recycling of Rare Metals, (CMC Publishing Co., Ltd., Tokyo, 2008) pp. 332-350.

5) Web-Site of JOGMEC Mineral Resource Information Center: http://www.jogmec.go.jp/mric web/jouhou/material/2008/ PGM.pdf, (Status: 2010/Apr/15).

6) Y. Adachi, Y. Matsuno, I. Daigo and H. Takiguchi: Advanced LCA Methodology for a Sustainable Society, (University of Tokyo Press, Tokyo, 2004) pp. 159-181.

7) T. Hirato, I. Daigo, Y. Matsuno and Y. Adachi: Tetsu-toHagane 95 (2009) 96-101.

8) K. Harada, K. Ijima, M. Shimada and N. Katagiri: J. Japan Inst. Metals 73(2009) 151-160.

9) M. Saurat and S. Bringezu: Journal of Industrial Ecology 13 (2009) 406-421.

10) David Jollie: Platinum 2009, (Johnson Matthey, England; Japanese: Tanaka Kikinzoku Kogyo).

11) Japan Automobile Manufacturers Association, Inc.: World Motor Vehicle Statistics, (Japan Automobile Manufacturers Association, Inc., Tokyo, 2009).

12) M. Fuse and S. Kashima: Journal of the Japan Society of Waste Management Experts 18(2007) 305-313.

13) S. Nakamura, N. Kojima and K. Yokoyama: Journal of MMIJ 123 (2007) 799-802.

14) T. Okura: Kinzoku 76(2006) 1030-1033.

15) S. Kondo, A. Takeyama and T. Okura: Shigen to Sozai 122 (2006) 386-395.

16) T. Hamada, H. Yamasaki and S. Hitomi: Kinzoku $\mathbf{7 6}$ (2006) 998-1004.

17) Automobile Inspection \& Registration Information Association: Jikenkyo-Tokei Jidosha Hoyu Sharyosu, (Automobile Inspection \& Registration Information Association, Tokyo, 1975-2008).

18) Web-Site of Japan Used Motor Vehicle Exporters Association: http://www.jumvea.or.jp/j/info/info.php?srch _ flag = 1\&ca id $=12 \& \mathrm{ca}_{\text {id }}=12 \&$ if $\_$id $=48 \&$ if $\_$kubun $=\&$ page $=1 \&$ sum count $=1 \&$ kensuu $=1$, (Status: 2010/Apr/15) . 